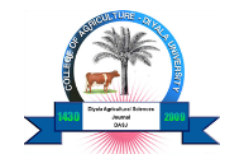

Web site: https://journal.djas.uodiyala.edu.iq/ https://dx.doi.org/10.52951/dasj.21130103

ISSN: 2073-9524 (Print)

ISSN: 2310-8746 (Online)

\title{
Auxins and Cytokinins Involved in Micropropagation of Pepino Plant (Solanum muricatum Aiton)
}

\author{
Waad S. Faizy ${ }^{1}$ Rafail S. Toma ${ }^{2}$, Yousif S. Tamer ${ }^{3}$, and Wisam Khaza'al ${ }^{4}$ \\ ${ }^{1}$ Department of Plant Production Techniques, Agricultural Technical College, Northern Technical \\ University, Iraq \\ ${ }^{2}$ Department of Horticulture, College of Agricultural Engineering Sciences, Uinversity of Duhok, \\ Kurdistan Region-Iraq \\ ${ }^{3}$ Ministry of Education, Kurdistan Region-Iraq \\ ${ }^{4}$ Department of Horticulture and Landscape Design, College of Agriculture and Forestry, University of \\ Mosul, Iraq \\ ${ }^{2}$ Correspondant Author: Rafail S. Toma rshtoma@uod.ac
}

\begin{abstract}
A reliable and successful micropropagation protocol was developed for pepino plant (Solanum muricatum Aiton) from nodal segment explants grown on MS medium. The best values of shoot multiplication traits were recorded from the addition of $3 \mathrm{mg}^{-1}{ }^{-1}$ kinetin by producing 2.3 shoots/explant, $3.6 \mathrm{~cm}$ and 9.6 leaves/ explant which was significantly superior upon the addition of BA at the same levels. In case of adding $3 \mathrm{mg} . \mathrm{l}^{-1}$ kinetin, the best root formation attributes were achieved from the use of $0.2 \mathrm{mg} .1^{-1}$ IAA that resulted a maximum number of roots (14.33 roots/ explant). The longest root length $(15.33 \mathrm{~cm})$ was achieved when $0.3 \mathrm{mg} . \mathrm{l}^{-1}$ IAA was used. A $100 \%$ rooting percentage was recorded from the all tested auxins including IAA, IBA and NAA. The gradually moved plantlets from the heterotrophic phase in the lab to the autotrophic phase in the greenhouse showed $100 \%$ success. The plantlets did not show any abnormal growth or morphological changes. It is concluded that this important plant can be easily propagated by tissue culture technique through a reliable micropropagation protocol.
\end{abstract}

Keywords: IAA, IBA, Kinetin, Micropropagation, NAA, Pepino, Solanum muricatum Aiton

\section{Introduction}

Pepino dulce is the common name of Solanum muricatum, it belongs to the family solanaceae and genus Solanum (Ipgri and Comav, 2004). It is one of the subtropical evergreen shrubs natively present in several countries of South America. It is commercially propagated in Australia, USA, New Zealand, Turkey, etc. (Aghdaei et al., 2019). It comes in different colors and shapes. The name pepino comes from the Spanish language which means"cucumber" because it is similar to cucumber in texture and taste especially at the premature stage but when it matures, the taste becomes sweet that is why it is called sweet cucumber (Orhanet al., 2014).

\section{Dates:}

Received: 02 March 2021
Published: 30 June 2021 
This plant is widely used as an ingredient in many food meals, salads and desserts (Prohens et. al., 1996). Pepino fruit contains water (92\%). It is rich in potassium and vitamin $\mathrm{C}$ about 1000 mg. $\mathrm{kg}^{-1}$ and $200 \mathrm{mg} . \mathrm{kg}^{-1}$ respectively and with a reasonable amount of thiamine and minerals (Pluda et.al., 1993, Sánchez et. al., 2000, Sudha et. al., 2011 and AghdaeI et. al., 2019). In spite of its nutritive value, it has been proved that this plant has several medicinal values such as it relieve hypertension act as antioxidant, antitumoral and diuretic (Cavusoglu, and Sulusoglu 2013) as well as it is widely used as Hepatoprotective. Pepino is a crop that is usually grown in the greenhouse and when compared with other greenhouse crops, it has a longer growing season with a yield about 75 tons.ha ${ }^{-1}$ (Prohens and Nuez, 1999). Pepino could be propagated either by seeds or vegetatively by cuttings. However, natural propagation via seed has many problems as a low rate of seed germination with low quality plants and high heterozygosity levels (Nemati and Tehranifar, 2007). To overcome these problems it could be propagated via tissue culture from vegetative parts which produce seedlings with high quality and homozygosity levels (Jordan et. al, 1990a, 1990b and Jordan et. al, 1993). Moreover, micropropagation is a great tool used in plant breeding fields as gene transformation and intergeneric hybrids (Sakomoto and Taguchi, 1991). Aysun and Melekber (2013) developed a protocol for Pepino micropropgation from leaves and nodes. They tested different combinations of BA, NAA and IBA on pepino plantlets grown on MS medium.

The objective of the present study was the micropropagation of pepino plant from nodal segments for mass production of healthy and vigorous transplants as well as to introduce this new plant to our farming community and the general public.

\section{Materials and Methods}

Nodal segments of pepino were taken from mature plants as explants and they were surface sterilized by $10 \%$ of commercial bleach $(\mathrm{NaOCl})$ for 10 minutes then thouroghly washed 3 times with sterilized dist. water each for three minutes. Then the nodal segments were cultured on MS Basal Medium (Murashige and Skoog, 1962). For multiplication stage MS medium was supplemented with BA (0, 1, 2 and 3) mg.l-1 and kinetin (0, 1, 2 and 3) mg.l-1. Furthermore, at rooting stage three kinds of auxins were tested including NAA, IBA and IAA at $0,0.1,0.2$ and $0.3 \mathrm{mg} .1-1$ with $0.5 \mathrm{mg} .1-1 \mathrm{BA}$ or $3 \mathrm{mg} .1-1$ Kinetin. Data were recorded on the shoots number/ explant, leaves number/ explant and mean length of shoots $(\mathrm{cm})$ for the shoots multiplication stage. For the rooting stage, roots number/ explant, mean length of roots $(\mathrm{cm})$ and the percentage of rooting $(\%)$ was determined in response to various treatments. The explants disinfistation and culture process were done under the aseptic conditions of the air-flow cabinet. The cultures were kept at the growing room area under controlled conditions at $25 \pm 2{ }^{\circ} \mathrm{C}$ and light illumination of 16 hrs light and 8 hrs darkness under 1000 Lux light intensity.

\section{Results and Discussion}

Amost $100 \%$ of healthy cultures were achieved from the initiation stage of pepino nodal segment explants grown on MS medium after a successful disinfestation with $\mathrm{NaOCl}(10 \%)$ for 10 minutes (Fig.1, A). These results assure the vital Influence of sodium hypochlorite being the best option for getting healthy in vitro culture (Toma, 2019). Table (1) illustrates the influence of BA and kinetin on the shoot multiplication stage of pepino explants cultured on MS medium after six weeks in culture. It is clear from the table that the best results were achieved when 3 
mg.l-1 kinetin was used which resulted in the maximum number of shoots explant-1 (2.3) shoots/explant, shoot length $(3.6 \mathrm{~cm})$ with the highest number of leaves explant-1 (9.6). While the least number of shoot per explant and the shortest mean length were acquired when $3 \mathrm{mg} .1-1$ BA was added by producing 1 shoot and $0.46 \mathrm{~cm}$ respectively. While the lowest number of leaves per explant was obtained when $2 \mathrm{mg} .1$-1BA was used with 4.3 leaves/ explant. These results are in agreement with what has been reorted by Aysun and Melekber (2013) that cytokinins are essential for inducing pepino shoot multiplication. The roles of cytokinins is well known in enhancing shoot multiplication by their positive actions on breaking apical dominance, bud flushing up and proteins synthesis. Thus, adding cytokinins usually promote shoot multiplication of explants grown on culture media supplemented with propal concentrations (Aysun and Melekber, 2013).

Table 1. Influence of BA and kinetin on shoot multiplication stage of Pepino explants grown on MS medium after six weeks in culture

\begin{tabular}{|l|c|c|c|}
\hline Treatments & $\begin{array}{l}\text { Number of } \\
\text { Shoots/ Explant }\end{array}$ & $\begin{array}{l}\text { Shoots length } \\
(\mathrm{cm})\end{array}$ & $\begin{array}{l}\text { Number of } \\
\text { Leaves/ Explant }\end{array}$ \\
\hline \hline 0.0 & $1.3 \mathrm{~b}$ & $2.83 \mathrm{~b}$ & $7.6 \mathrm{~b}$ \\
\hline \hline BA $\left(1.0 \mathrm{mg} . \mathrm{l}^{-1}\right)$ & $1.3 \mathrm{~b}$ & $1.00 \mathrm{c}$ & $4.67 \mathrm{~d}$ \\
\hline \hline BA $\left(2.0 \mathrm{mg} . \mathrm{l}^{-1}\right)$ & $1.3 \mathrm{~b}$ & $0.92 \mathrm{c}$ & $4.3 \mathrm{~d}$ \\
\hline \hline BA $\left(3.0 \mathrm{mg} . \mathrm{l}^{-1}\right)$ & $1.0 \mathrm{c}$ & $0.46 \mathrm{~cd}$ & $2.6 \mathrm{e}$ \\
\hline \hline Kinetin $\left.1.0 \mathrm{mg} . \mathrm{l}^{-1}\right)$ & $1.6 \mathrm{~b}$ & $2.16 \mathrm{~b}$ & $6.3 \mathrm{c}$ \\
\hline \hline Kinetin $\left.2.0 \mathrm{mg} . \mathrm{l}^{-1}\right)$ & $1.6 \mathrm{~b}$ & $2.83 \mathrm{~b}$ & $6.6 \mathrm{c}$ \\
\hline \hline Kinetin $\left.3.0 \mathrm{mg} . \mathrm{l}^{-1}\right)$ & $2.3 \mathrm{a}$ & $3.6 \mathrm{a}$ & $9.6 \mathrm{a}$ \\
\hline
\end{tabular}

Table 2 shows the influence of IAA, IBA and NAA on the rooting stage of pepino shoots grown on MS medium enriched with $3.0 \mathrm{mg}$.l-l kinetin after six weeks in. In general, IAAwas better than the rest of auxins by producing better rooting parameters. The highest number of roots per explant was obtained when $0.2 \mathrm{mg} .1$-1 IAA was added by producing 14.33 roots/ explant. However, the longest mean of the root was obtained when $0.3 \mathrm{mg} .1-1$ IAA was added by giving $15.33 \mathrm{~cm}$ as mean shoots length. Moreover, the highest rooting rate (100\%) was acquired when IAA at $(0.1,0.2$ and 0.3$) \mathrm{mgl} .-1$, IBA at $0.3 \mathrm{mg} .1-$ land NAA at 0.2 and $0.3 \mathrm{mg} .1$-lwere used while the other gave $90 \%$. On the other hand the control treatment gave the lowest rooting parameters which were 3.33 roots/ explant, $4.55 \mathrm{~cm}$ mean shoot length and $30 \%$ rooting percentage.

Table 2. Influence of IAA, IBA and NAA on the rooting stage of Pepino shoots grown on MS medium enriched with $3.0 \mathrm{mg}^{-1} \mathrm{Kinetin}^{-1}$ after six weeks in culture

\begin{tabular}{|l|c|c|c|}
\hline Treatments & $\begin{array}{l}\text { Roots Number/ } \\
\text { Explant }\end{array}$ & Roots lenght $(\mathrm{cm})$ & $\begin{array}{l}\text { Rooting Percentage } \\
(\%)\end{array}$ \\
\hline \hline 0.0 & $3.33 \mathrm{e}$ & $4.55 \mathrm{~g}$ & $30 \mathrm{c}$ \\
\hline \hline IAA $\left(0.1 \mathrm{mg} . \mathrm{l}^{-1}\right)$ & $8.33 \mathrm{~d}$ & $13.67 \mathrm{~b}$ & $100 \mathrm{a}$ \\
\hline \hline IAA $\left(0.2 \mathrm{mg} . \mathrm{l}^{-1}\right)$ & $14.33 \mathrm{a}$ & $15.00 \mathrm{a}$ & $100 \mathrm{a}$ \\
\hline \hline IAA $\left(0.3 \mathrm{mg} . \mathrm{l}^{-1}\right)$ & $12.67 \mathrm{~b}$ & $15.33 \mathrm{a}$ & $100 \mathrm{a}$ \\
\hline \hline IBA $\left(0.1 \mathrm{mg} . \mathrm{l}^{-1}\right)$ & $10.33 \mathrm{c}$ & $9.33 \mathrm{c}$ & $90 \mathrm{~b}$ \\
\hline \hline IBA $\left(0.2 \mathrm{mg} . \mathrm{l}^{-1}\right)$ & $8.67 \mathrm{~d}$ & $7.00 \mathrm{f}$ & $90 \mathrm{~b}$ \\
\hline \hline IBA $\left(0.3 \mathrm{mg} . \mathrm{l}^{-1}\right)$ & $11.00 \mathrm{~b}$ & $9.33 \mathrm{c}$ & $100 \mathrm{a}$ \\
\hline
\end{tabular}




\begin{tabular}{|l|c|c|c|}
\hline NAA $\left(0.1 \mathrm{mg} . \mathrm{l}^{-1}\right)$ & $11.67 \mathrm{~b}$ & $7.67 \mathrm{de}$ & $90 \mathrm{~b}$ \\
\hline \hline NAA $\left(0.2 \mathrm{mg} . \mathrm{l}^{-1}\right)$ & $10.00 \mathrm{c}$ & $8.83 \mathrm{~d}$ & $100 \mathrm{a}$ \\
\hline \hline NAA $\left(0.3 \mathrm{mg} . \mathrm{l}^{-1}\right)$ & $13.33 \mathrm{a}$ & $7.83 \mathrm{e}$ & $100 \mathrm{a}$ \\
\hline
\end{tabular}

Table 3 illustrates the effect of IAA, IBA and NAA on the rooting stage of Pepino shoots grown on MS medium enriched with $0.5 \mathrm{mg} .1-1 \mathrm{BA}$ after six weeks in culture. Overall, the culture performance was better in the presence of $0.5 \mathrm{mg} .1-1 \mathrm{BA}$, IBA and NAA than IAAby giving the best results for rooting parameters. Accordingly, the highest number of roots/ explant was obtained when 0.1 mg.1-1 NAA was added (11.33 roots/ explant). Furthermore, the longest roots were achieved when $0.3 \mathrm{mg} .1-1$ IBA was added by giving $19.67 \mathrm{~cm}$. Moreover, the highest rooting percentage was acquired when $0.1,0.2$ and $0.3 \mathrm{mg} .1-1$ IBA were used by reaching $100 \%$. Nevertheless, the lowest number of roots and rooting percentage were obtained for control treatment which gave only 3.33 roots/ explant and $30 \%$ rooting percentage. While the shortest roots were acquired when $0.3 \mathrm{mg}$.1-1NAA was added by producing a $3.67 \mathrm{~cm}$ root length. These results confirm the importance of auxins in inducing adventitious root formation on micro-shoots (Toma, 2019).

Table 3. Influence of IAA, IBA and NAA on the rooting stage of Pepino shoots grown on MS medium enriched with $0.5 \mathrm{mg.l}^{-1} \mathrm{BA}$ after six weeks in culture

\begin{tabular}{|l|c|c|c|}
\hline Treatments & $\begin{array}{l}\text { Roots number/ } \\
\text { Explant }\end{array}$ & Roots length $(\mathrm{cm})$ & $\begin{array}{l}\text { Rooting } \\
\text { Percentage (\%) }\end{array}$ \\
\hline \hline 0.0 & $3.33 \mathrm{e}$ & $4.55 \mathrm{f}$ & $30 \mathrm{e}$ \\
\hline \hline IAA $\left(0.1 \mathrm{mg} . \mathrm{l}^{-1}\right)$ & $6.33 \mathrm{c}$ & $17.83 \mathrm{~b}$ & $80 \mathrm{~d}$ \\
\hline \hline IAA $\left(0.2 \mathrm{mg} . \mathrm{l}^{-1}\right)$ & $8.33 \mathrm{~b}$ & $14.50 \mathrm{c}$ & $85 \mathrm{c}$ \\
\hline \hline IAA $\left(0.3 \mathrm{mg} . \mathrm{l}^{-1}\right)$ & $10.67 \mathrm{a}$ & $13.00 \mathrm{~d}$ & $90 \mathrm{~b}$ \\
\hline \hline IBA $\left(0.1 \mathrm{mg} . .^{-1}\right)$ & $7.33 \mathrm{~b}$ & $16.33 \mathrm{~b}$ & $100 \mathrm{a}$ \\
\hline \hline IBA $\left(0.2 \mathrm{mg} . \mathrm{l}^{-1}\right)$ & $7.67 \mathrm{~b}$ & $16.50 \mathrm{~b}$ & $100 \mathrm{a}$ \\
\hline \hline IBA $\left(0.3 \mathrm{mg} . \mathrm{l}^{-1}\right)$ & $7.67 \mathrm{~b}$ & $19.67 \mathrm{a}$ & $100 \mathrm{a}$ \\
\hline \hline NAA $\left(0.1 \mathrm{mg} . \mathrm{l}^{-1}\right)$ & $11.33 \mathrm{a}$ & $14.33 \mathrm{c}$ & $80 \mathrm{~d}$ \\
\hline \hline NAA $\left(0.2 \mathrm{mg} . \mathrm{l}^{-1}\right)$ & $8.33 \mathrm{~b}$ & $8.83 \mathrm{e}$ & $80 \mathrm{~d}$ \\
\hline \hline NAA $\left(0.3 \mathrm{mg} . \mathrm{l}^{-1}\right)$ & $7.67 \mathrm{~b}$ & $3.67 \mathrm{~g}$ & $85 \mathrm{c}$ \\
\hline
\end{tabular}

The produced plantlets were carefully acclimatized and gradually moved from the lab conditions to the greenhouse with a high survival rate (100\%). The acclimatized plantlets were grown normally and showed no abnormal characteristics in their morphology (Fig. 1). 


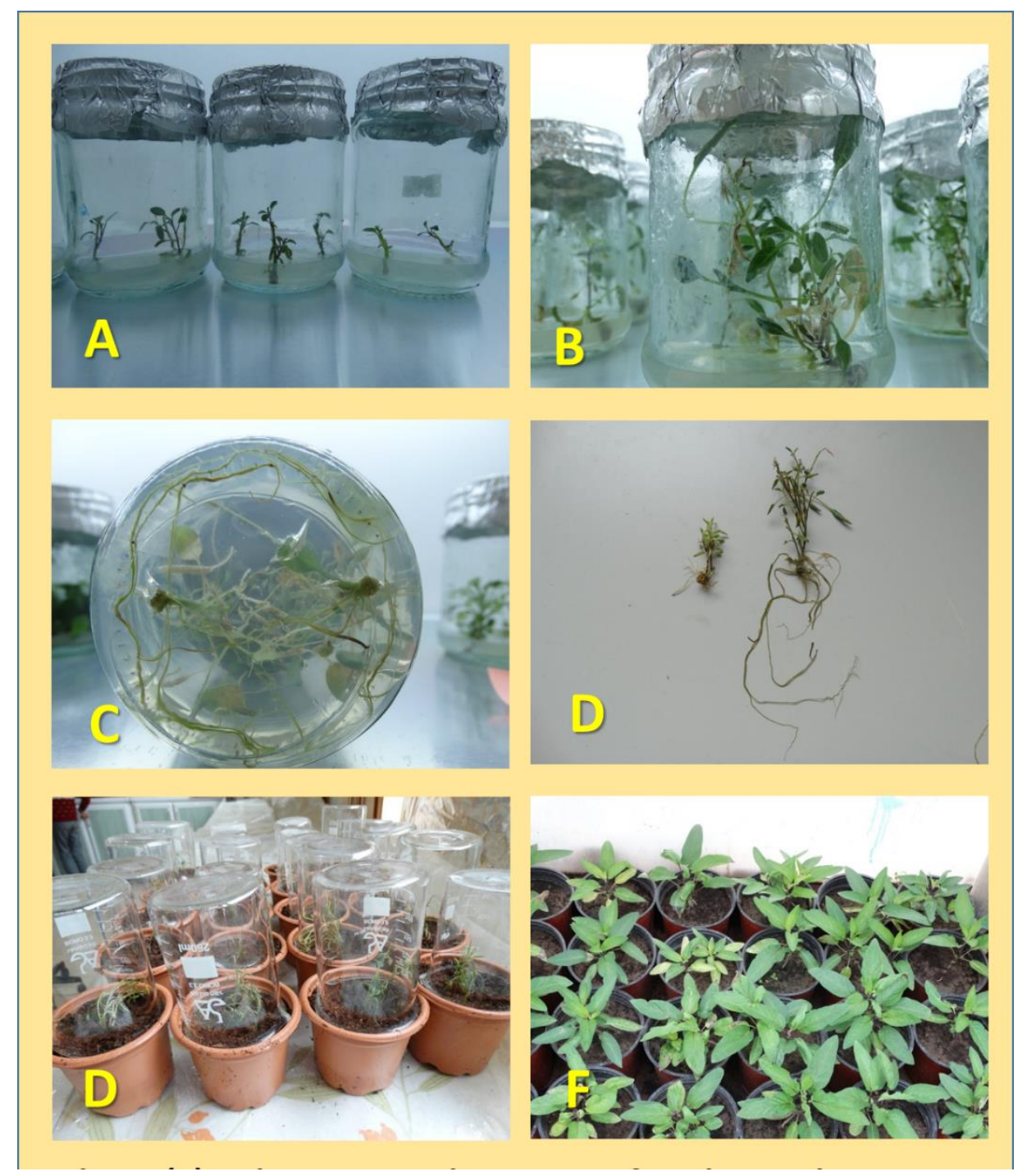

Figure 1. Micropropagation stages of Pepino explants grown on MS medium: A: Explants initially inoculated on the medium. B: Six weeks growing explants on shoot multiplication medium. C: Well rooted shoots at root formation stage. D: The best rooting treatment (Kinetin $3.0 \mathrm{mg} .1-1)$ vs. Control. E: The beginning of hardening stage. F: Well acclimatized Pepino plantlets under greenhouse conditions.

\section{Conclusions}

In conclusion. This newly introduced plant to the Kurdistan Region of Iraq can be readily propagated by tissue culture technique and it is highly recommended to be commercially produced towards mass production to meet the local community demand.

\section{Conflict of interest}

The authors declare that they have no competing interests. 


\section{Aknowledgment}

Special thanks and appreciations go to the Department of Horticulture at the College of Agricultural Engineering Sciences, UoD for providing the lab of plant tissue culture and the well equipped greenhouse to conduct this investigation.

\section{References}

Aghdai, M.; Nemati, S. H.; Samiee, L. and Sharifi, A. 2019. Influence of rooting medium, cutting type and auxin on rooting of pepino (Solanum muricatum aiton.) Applied Ecology and Environmental Research. 17(5):10357-10369.

Aysun, C. and S. Melekber . 2013. In vitro propagation and acclimatization of pepino (Solanum muricatum). Journal of Food, Agriculture and Environment. 11(1): 410-415.

Cavusoglu, A., \& Sulusoglu, M. 2013. In vitro propagation and acclimatization of pepino (Solanum muricatum). Journal of Food Agriculture Environment, 11, 410-415.

Ipgri and Comav. 2004. Descriptors for pepino (Solanum muricatum), International Plant Genetic Recources Institute, Rome, Italy and Centro de Conservacion y Mejora de la Agrodiversidad Valenciana, Valencia, Spain.

Jordan, M.; Arce, P.; Gutiérrez, A. and Roveraro, C. 1990a. Inducción de respuestas morfogénicas in vitro mediante co-cultivo de diferentes especies frutales. Cienc. Investigación Agraria 17(1-2):13-17.

Jordan, M.; Arce, P.; Gutiérrez, A. and Roveraro, C. 1990b. Micropropagación in vitro de algunas especies frutícolas de Chile. Cienc. Investigación Agraria 17(3):111-116.

Jordan, M.; Obando, M.; Iturriaga, L.; Goreux, A. and Velozo, J. 1993. Organogenesis and regeneration of some Andean fruit species. Acta. Hort. 336:279-284.

Murashige, T., \& Skoog, F. 1962. A revised medium for rapid growth and bio assays with tobacco tissue cultures. Physiologia plantarum, 15(3), 473-497.

Orhan, N.; Orhan, D. D.; Aslan, M. and Ergun, F. 2014. Influence of exotic fruit "pepino" (Solanum muricatum aiton.) on blood glucose level.Turk. J. Pharm. Sci. 11(2): 195-202.

Pluda, D.; Rabinovitch, H. D. and Kafkafi, U. 1993. Pepino dulce (Solanum muricatum Ait.) quality characteristics respond to nitrogen nutrition and salinity, J. Am. Soc. Hortic. Sci. 118: 86-91.

Prohens, J., and Nuez, F. 1999. Strategies for breeding a new greenhouse crop, the pepino (Solanum muricatum Aiton). - Canadian Journal of Plant Science 79: 269-275.

Prohens, J.; Ruiz, J. and Nuez, F. 1996. The pepino (Solanum muricatum, Solanaceae): A new crop with a history, Econ Bot 50(4): 355-368.

Ren, W. P. and Tang, D. G. 1999. Extract of Solanum muricatum (pepino/csg) inhibits tumor growth by inducing apoptosis, Anticancer Res 19(1A): 403-408.

Sakomoto, K. and Taguchi, T. 1991. Regeneration of intergeneric somatic hybrid plants between Lycopersicon esculentum and Solanum muricatum. Theor. Appl. Genet. 81:509-513. 
Sánchez, M.; Cámara, M.; Prohens, J.; Ruiz, J. J.; Torija, E. and Nuez, F. 2002. Variation in carbohydrate content during ripening in two clones of pepino, J. Sci. Food Agric. 80: 1985-1991.

Sudha, G.; Priya, M. S.; Shree, R. I. and Vadivukkarasi, S. 2011. In vitro free radical scavenging activity of raw pepino fruit (Solanum muricatum aiton). International Journal of Current Pharmaceutical Research 3(2): 137-140.

Toma, R. S. 2019. Cost Influence ive Culture Medium for Micropropagation of Paulownia (Paulownia tomentosa Steud.) and Catalpa (Catalpa bignonioides Walt.). The Arabian Journal of Agricultural sciences. 2(4). 33-46. 